Warditiani dkk.

DOI : https://doi.org/10.24843/JFU.2020.v09.i01.p09

pISSN: 2301-7716; eISSN: 2622-4607

Jurnal Farmasi Udayana, Vol 9, No 1, Tahun 2020, 62-65

\title{
Analisa Kesukaan Produk Balsem Aroma Bunga
}

\author{
Warditiani N.K. ${ }^{*}$, Arisanti C.I.S. ${ }^{1}$, Swastini D.A ${ }^{1}$, Wirasuta I.M.A.G ${ }^{1}$ \\ ${ }^{1}$ Program Studi Farmasi Fakultas Matematika dan Ilmu Pengetahuan Alam Universitas Udayana, Jalan Kampus Unud, \\ Jimbaran, 80364 \\ E-mail:kadektia@unud.ac.id
}

Riwayat artikel: Dikirim: 09/05/2020; Diterima: 19/06/2020, Diterbitkan: 25/06/2020

\begin{abstract}
Balm is a thick oil containing resin oil and essential oils, feels hot. Balm is applied by rubbing and rubbing on the skin. The balm has the benefit of reducing muscle aches, which are caused by the burning sensation of the balm. Essential oils can cause a refreshing and soothing sensation after the use it. This balm can calm consumers who experience muscle pain. The aim of this study is to find out the best formula preferred by consumers aged 20 to 60 years. The method of this study is a qualitative analysis, based on the answers of questionnaires by respondent. Four balm formula was tested, namely Balm no 1, Balm no 2, Balm no 3, Balm no 4. The parameter assessed is aroma, texture, color and warm sensation. The results show that the description of male consumers (54.5\%), women (45.5\%), ages 20-30 years (45.5\%), ages $31-40$ years $(27.3 \%)$, ages $41-50$ years $(18.2 \%)$, aged 51 years and over $(9 \%)$. The results showed that most respondent liked Balm No. 4, both in terms of aroma, texture, color and warm sensation. It is expected that this warm feeling will be able to reduce the aches in the muscles of respondent. Balm No. 4 has been registered with a patent registration number S00202003544.
\end{abstract}

Keywords: balm, product assessment, balm no. 4, warm sensation

\begin{abstract}
ABSTRAK
Balsem adalah minyak kental yg mengandung minyak damar dan minyak asiri, terasa panas. Aplikasi balsem adalah dengan dioles dan digosok pada kulit. Manfaat penggunaan balsem adalah mengurangi rasa pegal pada otot, yang disebabkan karena rasa panas dari balsem. Kandungan minyak atsiri dari bunga menyebabkan sensasi menenangkan setelah penggunaan balsem, sehingga mampu menenangkan responden yang mengalami nyeri otot. Tujuan dari penelitian ini adalah untuk mengetahui formula terbaik yang disukai oleh responden dengan usia 20 hingga 60 tahun. Metode uji dari penelitian ini adalah analisis kualitatif yang mengacu pada jawaban kuisioner yang diisi oleh responden pria dan wanita dengan rentang usia 20 ke atas. Formula balsam yang diujikan sebanyak 4 yaitu Balsem no 1, Balsem no 2, Balsem no 3, Balsem no 4. Hasil yang diperoleh dari segi aroma, tekstur, warna dan sensasi hangat yang ditimbulkan dari sediaan. Hasil menunjukkan bahwa deskripsi responden pria (54,5\%), wanita (45,5\%), usia 20-30 tahun (45,5\%), usia 31-40 tahun (27,3\%), usia $41-50$ tahun (18,2\%), usia 51 tahun ke atas (9\%). Hasil menunjukkan bahwa sebagian besar responden menyukai Balsem no 4, baik dari segi aroma, tekstur, warna dan sensasi hangat. Diharapkan rasa hangat ini akan mampu mengurangi rasa pegal-pegal pada otot responden. Balsem no 4 telah didaftarkan paten dengan no pendaftaran S00202003544.
\end{abstract}

Kata kunci: balsem, analisa kesukaan, Balsem no 4, sensasi hangat

\section{PENDAHULUAN}

Balsem adalah sediaan topikal yang memberi sensasi hangat, sediaan ini termasuk semisolid yang mampu memberi rasa lembut dan berminyak pada kulit. Balsem merupakan sediaan seperti salep yang mudah dioleskan (Anonim, 1995). Sediaan balsam yang merupakan sediaan semisolid memiliki formula acuan yaitu paraffin atau lilin (sebagai pemadat), vaselin album atau flavum (sebagai pengawet), kampor (sebagai pengawet), mentol 
DOI : https://doi.org/10.24843/JFU.2020.v09.i01.p09

pISSN: 2301-7716; eISSN: 2622-4607

Jurnal Farmasi Udayana, Vol 9, No 1, Tahun 2020, 62-65

(sebagai pemberi sensasi dingin) dan dapat ditambahkan minyak-minyak mudah menguap (minyak atsiri).

Minyak atsiri merupakan salah satu metabolit sekunder yang terkandung dalam tanaman baik dari daun, batang, akar, rimpang, bunga dan buah. Minyak atisiri ini memiliki aroma yang khas. Khasiat minya atsiri dapat menenangkan (Buchbauer dkk., 2007; Ali dkk., 2015), menghangatkan, antibakteri, anti jerawat, antiinflamasi, analgesic (Kazemivash and Asgapanah, 2009) maupun antioksidan (Wei and Shibamoto, 2010). Penggunaan minyak atsiri mampu memberikan sensasi hangat dan memberikan aroma yang menenangkan atau menyegarkan bagi responen.

Pada penelitian ini, dilakukan pengujian kesukaan dari empat balsam yang dihasilkan pada responden pria maupun wanita dewasa. Hal ini bertujuan untuk mengetahui balsam manakah yang memberikan sensasi hangat, wujud dan aroma yang paling disukai.

\section{BAHAN DAN METODE}

\section{Bahan dan Alat Penelitian}

Bahan-bahan yang digunakan dalam pembuatan Balsem ini adalah vaselin, parafin padat, parafin cair, mentol, champer dan essential oil, lembar kuisioner.

Peralatan yang digunakan dalam pembuatan balsam adalah cawan porselin, kompor, batang pengaduk, timbangan, pot balsem

\section{Metode}

\section{Pembuatan balsem}

Semua bahan ditimbang sesuai komposisi pada tabel 1, lalu cairkan bahan yang padat dengan metode pemanasan. Setelah semua cair, dilakukan pencampuran terhadap semua bahan termasuk essential oil. Diaduk hingga semua bahan mulai memadat, lalu dimasukkan ke dalam wadah pot.

\section{Analisa Kesukaan}

Analisis kepuasan yang dilakukan oleh penulis adalah analisis deskriptif terhadap kesukaan pengguna terhadap balsam 1 hingga 4. Parameter yang dinilai adalah wujud fisik, aroma dan sensasi hangat yang dihasilkan. Dari penelitian deskriptif ini, data diolah sedemikian rupa hingga menghasilkan suatu pemodelan korelatif yang dapat menggambarkan hubungan antara informasi dengan kesukaan responden.

Penulis menggunakan metode kuisioner untuk mendapatkan informasi dari responden. Dimana kuisioner disebar kepada 110 responden yaitu responden dari usia 20 tahun keatas, baik pria maupun wanita di daerah Denpasar. Skala kesukaan yang digunakan penulis yaitu sangat suka, suka, kurang suka dan tidak suka. Teknik pengumpulan data yang digunakan dalam penelitian kuatitatif adalah dengan menggunakan menanyakan kesukaan responden yaitu dengan cara melakukan penyebaran kuisioner. Dokumentasi dan wawancara merupakan teknik pengumpulan data dengan cara membaca dan menyakan, mengolah laporan-laporan serta catatan yang menunjang penelitian ini.

\section{HASIL}

Balsem yang dibuat sebanyak empat jenis, dimana yang dilakukan variasi adalah pada jumlah mentol, parafin padat, dan parafin cair. Hal ini mengakibatkan perbedaan dalam wujud, aroma dan sensasi hangat yang dihasilkan. Tentunya hal ini dijadikan sebagai bahan pertimbangan dalam mengetahui kesukaan dari responden.

Tabel 1. Komposisi bahan dari masing-masing balsem

\begin{tabular}{lcccc}
\hline Komposisi & Balsem 1 (\%) & Balsem 2 (\%) & Balsem 3 (\%) & Balsem 4 (\%) \\
\hline Champor & 20,8 & 20,8 & 20,8 & 20,8 \\
Mentol & 10,4 & 10,4 & 15,6 & 15,6 \\
Paraffin padat & 20,8 & 26,0 & 20,8 & 10,4 \\
Paraffin cair & 5,2 & - & - & 10,4 \\
Vaselin album & 35,5 & 35,5 & 35,5 & 35,5 \\
Essential oil & 7,3 & 7,3 & 7,3 & 7,3 \\
\hline
\end{tabular}


Wujud sediaan balsem 1 hingga 4 tampak pada gambar 1. Tampak bahwa dengan terdapat perbedaan fisik antar balsem, baik warna maupun wujudnya. Balsem 1 dan 2 warnanya lebih putih tetapi wujudnya lebih keras, sedangkan balsem 3 dan 4 terlihat lebih berwarna krem dengan wujud lebih lunak (berminyak). Pada gambar 2, merupakan deskripsi responden yang bersedia mengisi kuisinier kesukaan dari keempat balsem. Jumlah responesn pria $(54,5 \%)$ lebih banyak dibandingkan responden wanita (45,5\%). Sedangkan responden yang berusia 20-30 tahun memiliki jumlah yang paling banyak yaitu 45,5\% sedangkan jumlah responden yang paling sedikit berusia diatas 50 tahun. Gambar 3, tampak bahwa balsem 4 merupakan balsem yang paling banyak disukai oleh responden. Balsem 4 memiliki tekstur yang lembut, semi solid dan mudah diaplikasikan pada kulit. Memiliki aroma yang diminati, lembut dan tidak begitu menyengat. Sensasi panas yang ditimbulkan juga cukup, sehingga mampu mengurangi rasa pegal-pegal pada otot. Balsem 4 mendapatkan penilaian terhadap wana, tekstur, aroma dan sensasi hangat yang sangat disukai.

\section{PEMBAHASAN}

Balsem aroma bunga ini terdiri dari bahan champor, mentol, parafin padat, parafin cair, vaselin album dan aromanya dari essential oil. Keempat balsem ini dilakukan variasi terhadap jumlah mentol, parafin padat, dan parafin cair. Sedangkan jumlah camphor dan essential oil tetap untuk keempat formula balsem ini.

Camphor merupakan produk olahan yang berasal dari kayu tanaman Cinnamomum camphora $\mathrm{L}$. yang dihasilkan dengan metode destilasi uap (Compadre dkk., 1986). Camphor yang dihasilkan ini memiliki khasiat farmakologis sebagai antiseptic, analgesic, antipuritik, dan penghambat iritasi (Ellenhorn and Barceloux, 1998). Efek analgesik yang dihasilkan oleh camphor dapat digunakan secara topical dan biasanya menimulkan sensasi hangat atau panas, dan dapat digunakan sebagai bahan balsam (Xu et al., 2005). Mentol merupakan komponen alami yang dihasilkan dari tanaman Mentha piperita L. secara luas, mentol dimanfaatkan sebagai bahan tambahan pada kosmetik ataupun sediaan topical. Penggunaan mentol akan memberikan sensasi dingin pada kulit

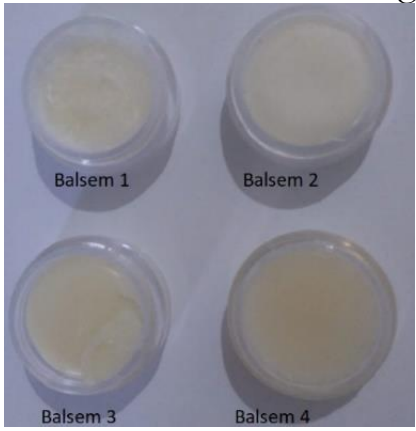

Gambar 1. Sediaan Balsem 1 - 4

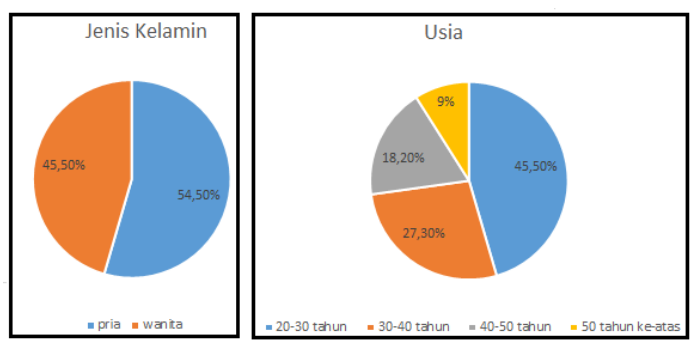

Gambar 2. Deskripsi responden yang bersedia mengisi kuisioner, yaitu berdasarkan jenis kelamin dan usia responden

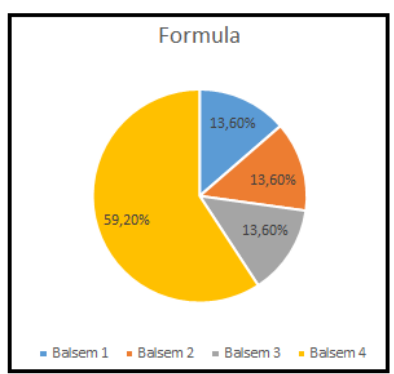

Gambar 3. Deskripsi kesukaan responden terhadap balsem 1 hingga balsem 4

dan hal ini dimanfaatkan untuk obat tradisional di beberapa negara (Patel dkk., 2007).

Penggunaan mentol pada produk topical, memiliki khasiat sebagai analgesik dan memberikan sensasi dingin yang cocok untuk mengatasi nyeri lokal. Mentol dapat berperan sebagai analgesic karena mampu mentol mampu menambah penetrasi karena mentol mampu bermanfaat pada TRPM8 (Transient receptor potential melastatin family member 8), TRPA1 (Transient receptor potential subfamily A, member 1), dan kanal natrium sehingga menjanjikan sebagai obat analgesik baru (Joseph and Oliver, 2013). 
Warditiani dkk.

DOI : https://doi.org/10.24843/JFU.2020.v09.i01.p09

pISSN: 2301-7716; eISSN: 2622-4607

Jurnal Farmasi Udayana, Vol 9, No 1, Tahun 2020, 62-65

Vaselin album merupakan bahan semisolid yang jika dipanaskan akan mencair. Vaselin tidak berwarna, berbau dan berasa. Vaselin memiliki titik lebur $38-60^{\circ} \mathrm{C}$. Pada sediaan topical digunakan sebahai emollient (Depkes RI, 1979).

Parafin cair dikenal juga sebagai minyak mineral yaitu minyak kental tidak berwarna dan transparan. Paraffin cair tidak berwarna, berasa dan berbau (Sheng, 2009). Paraffin padat memiliki organoleptic sama dengan paraffin cair yaitu tidak berwarna, berasa dan berbau. Paraffin padat memiliki titik lebur $45-65^{\circ} \mathrm{C}$ (Rowe dkk., 2009).

Dari uji kesukaan didapatkan bahwa balsam 4 yang paling banyak diminati oleh responden yaitu sebanyak 59,2\%. Pada kuisioner semua responden memberikan penilaian yang sangat suka terhadap balsam 4 baik dari warna, tekstur, aroma dan sensasi hangat. Hal yang disukai adalah dari segi tekstur yang tidak terlalu padat sehingga mudah diaplikasikan pada kulit, sensasi hangat yang ditimbulkan setelah aplikasi pada kulit serta diakhiri dengan rasa dingin. Selain mampu mengurangi rasa pegal setelah digunakan pada kulit, juga mampu memberikan rasa yang menenangkan karena penggunaan essensial oil dari bunga dan rempah. Balsem no 4 ini juga telah didaftarkan paten dengan no pendaftaran S00202003544.

\section{KESIMPULAN}

Hasil analisa tingkat kesukaan balsam, dihasilkan bahwa jumlah responden terbanyak menyukai balsam 4 yang mana semua responden memberikan nilai sangat suka pada tekstur, warna, aroma dan sensasi hangat.

\section{UCAPAN TERIMAKASIH}

Penulis mengucapkan terima kasih kepada Kepala Laboratorium Farmasetika Dasar Program Studi Farmasi Universitas Udayana, Laboran Laboratorium Farmasetika Dasar Program Studi Farmasi Universitas Udayana serta semua responden yang telah bersedia menjadi subjek penelitian ini.

\section{DAFTAR PUSTAKA}

Ali, B., Al-Wabel, N.A., Shams, S., Ahamad, A., Khan, S.A., Anwar, F. (2015). Essential Oils
Used In Aromatherapy: A Systemic Review. Asian Pac J Trop Biomed. (8), 601-11.

Anonim. 1995. Farmakope Indonesia Edisi IV. Jakarta : Departemen Kesehatan Indonesia. Buchbauer,et al. (2017). Formulation and Activity Combination of Essential Oil in Aromatherapy of Wax. Journal of Essential Oil Research.6(1):124-127.

Compadre, C.M., Robbins, E., Kinghorn, A.D. (1986). The intensely sweet herb, Lippia dulcis Trev. historical uses, field enquiries, and constituents. J Ethnopharmacol. (15): 89-106. Ellenhorn, M.J., Barceloux, D.G. (1998). Camphor In Medical Technology: Diagnosis and treatment of human poisoning. New York: Elsevier, pp.: 505-507.

Joseph, A. F. and Oliver G. (2013). Menthol Pharmacology of an Important Naturally Medicinal "Cool". Mini-Reviews in Medicinal Chemistry, (13): 124-131

Kazemivash, N., and Asgapanah. (2009). Phtochemistry and Pharmacologic Properties of Myristica fragrans Houtt A review. African J Chem. 115(3):1114-9.

Patel, T., Ishiuji, Y., Yosipovitch, G., (2007). Menthol: a refreshing look at this ancient compound. J. Am. Acad. Dermatol, 57(5), 873-878.

Rowe, R.C., Paul, J.S., and Marian, E.Q., 2009). Handbook of Pharmaceutical Exipients, Pharmaceutical Press and American Pharmacist Association, USA. 808-809.

Sheng, J. J. (2009). Handbook of Pharmaceutical Excipients, $6^{\text {th }}$ ed, Pharmaceutical Press, Washington, pp.445-447.

Wei, A., and Shibamoto, T. (2010). Antioxidant/Lipoxygenase Inbibitory Activities and Chemical Compositions of Selected Essential Oils. J Agric Food Chem. 58(12) :7218-25.

Xu, H., Blair, N.T., Clapham, D.E. (2005). Camphor activates and strongly desensitizes the transient receptor potential vanilloid subtype 1 channel in a vanilloid-independent mechanism. $\mathrm{J}$ Neurosci. 25: 8924-8937

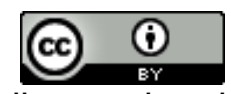

This work is licensed under a Creative Commons Attribution 4.0 International License 